УДК 343.22

DOI https://doi.org/10.32837/pyuv.v0i2(27).213

С. С. Колос

суддя апеляційного суду Вінницької області у відставці, старший викладач кафедри права

Вінницького національного аграрного університету

\title{
ВИНА ЮРИДИЧНОЇ ОСОБИ У КРИМІНАЛЬНО-ПРАВОВІЙ ДОКТРИНІ
}

Запровадження інституту кримінальної відповідальності юридичних осіб має загальносвітову тенденцію, адже необхідність посилення контролю за діловою активністю великих компаній, боротьби з корупцією, екологічними та терористичними злочинами вимагає посилення відповідальності юридичних осіб, які часто є причетними до таких злочинів. Україна не залишається осторонь, але протягом тривалого часу у кримінально-правовій доктрині можливість визнання юридичних осіб суб'єктами кримінальної відповідальності не розглядалася, адже таке визнання порушує низку традиційних принципів та інститутів кримінального законодавства.

Після набрання чинності Кримінальним процесуальним кодексом України 2012 року (далі КПК України) у ході євроінтеграційних процесів та реформування кримінального права Верховною Радою України з метою забезпечення виконання рекомендацій групи держав проти корупції, Спеціального комітету експертів Ради Свропи 3 питань оцінки заходів боротьби з відмиванням коштів та для реалізації низки міжнародних договорів України щодо встановлення відповідальності юридичних осіб 23 травня 2014 року було ухвалено Закон України «Про внесення змін до деяких законодавчих актів України щодо виконання Плану дій щодо лібералізації Європейським Союзом візового режиму для України стосовно відповідальності юридичних осіб». Вказаним Законом внесено зміни до Кримінального кодексу України (далі - КК України), КПК України, а також до законів України «Про засади запобігання і протидії корупції», «Про забезпечення безпеки осіб, які беруть участь у кримінальному судочинстві» та вперше в Україні передбачено застосування заходів кримінально-правового характеру до юридичної особи у разі вчинення від імені та в інтересах юридичної особи її уповноваженою особою злочину.

Сьогодні проблема притягнення до кримінальної відповідальності юридичної особи, визнання юридичної особи суб'єктом злочину залишається досить актуальною як з практичного, так і з теоретичного погляду. У вітчизняній кримінально-правовій науці все ще відсутня науково обгрунтована концепція впровадження інституту кримінальної відповідальності юридичних осіб. Особливо гострі дискусії стосуються вини юридичної особи (як однієї з обов'язкових ознак складу злочину), адже основоположним принципом в українському кримінальному праві є принцип особистої і винної відповідальності, а вина є однією з обов'язкових ознак складу злочину.

Проблема вини має загальнотеоретичне значення, оскільки вина є основним юридичним елементом, що характеризує психологічний зміст будь-якого правопорушення, тому вона досліджувалась представниками різних галузей юридичної науки.

Питання визнання юридичної особи суб’єктом злочину досліджували Р.В. Вереша, Б.В. Волженкін, С.Б. Гавриш, В.К. Грищук, У.С. Джекабаєв, Е.М. Кісілюк, В.М. Кудрявцев, С.Я. Лихова, В.В. Лунєєв, А.В. Наумов, А.С. Нікіфоров, С.I. Нікулін, А.В. Савченко, І.В. Сітковський, В.С. Устінов, П.Л. Фріс та інші.

Сучасні вчені відстоюють різні думки щодо визнання юридичних осіб суб'єктами злочину. Традиційно вважалося, що юридичні особи не підлягають кримінальній відповідальності внаслідок складності або навіть неможливості визначення вини таких осіб у скоєнні кримінального правопорушення, відсутності науково обгрунтованої системи кримінальних покарань юридичних осіб тощо. Деякі вчені вважають, що впровадження кримінальної відповідальності юридичних осіб не відповідає принципу особистої винної відповідальності і принципу індивідуалізації юридичної відповідальності та покарання. Однак прихильники протилежного погляду відстоюють свою позицію та вважають, що юридична особа є суб'єктом злочину, а вина не є необхідним елементом кримінальної відповідальності юридичних осіб. Отже, проблема вини юридичної особи у кримінально-правовій науці залишається досить актуальною та потребує подальших теоретичних досліджень.

Метою дослідження є аналіз основних концепцій вини у кримінально-правовій науці, визначення поняття вини юридичної особи як суб’єкта злочину.

У Конституції України одним з демократичних принципів правосуддя проголошується, що особа вважається невинуватою у вчиненні злочину і не може бути піддана кримінальному покаранню, доки її вину не буде доведено в законному порядку і встановлено обвинувальним вироком суду [4]. 
Чинний КК України завжди пов'язує відповідальність зі здатністю особи, яка вчинила суспільно небезпечне діяння, усвідомлювати свої дії та керувати ними. Стаття $23 \mathrm{KК}$ визначає вину як психічне ставлення особи до вчинюваної дії чи бездіяльності та ії наслідків, виражене у формі умислу або необережності [6].

Кримінальне право України заперечує відповідальність за наслідки, що настали в результаті будь-якого діяння, без встановлення вини. Відповідно до положень КК кримінальна відповідальність особи ґрунтується на суб'єктивному ставленні до вини як умови правильної соціально-політичної оцінки людської поведінки взагалі і злочинної зокрема. Отже, вина - це обов'язкова ознака суб'єктивної сторони будь-якого злочину, яка визначає його психологічний зміст і $є$ необхідною умовою кримінальної відповідальності [6].

Сутність вини визначає соціальну природу вини і полягає в негативному ставленні особи до тих інтересів, цінностей, благ (суспільних відносин), що охороняються КК. Форма вини - це поєднання певних ознак (елементів) свідомості і волі особи, яка вчиняє суспільно небезпечне діяння. Тому виникає запитання щодо того, чи можна застосувати поняття вини до юридичної особи.

На думку деяких учених, реформа вітчизняного кримінального законодавства, зумовлена запровадженням кримінальної відповідальності юридичних осіб, призведе до внутрішньої суперечності між нормами цієї галузі права та стане необгрунтованим кроком [7, с. 129].

Однак низка вчених відстоюе думку, що вина не $є$ необхідним елементом кримінальної відповідальності юридичних осіб. Зокрема, В.К. Грищук та О.Ф. Пасєка вважають, що якщо вину не вважати необхідною підставою, то юридичних осіб можна віднести до кримінально-правової сфери. Для фізичних осіб принцип вини у такому разі був би збережений, а на юридичних осіб він би не поширювався як виняток [5, с. 140-141].

Значна кількість вчених-правників взагалі заперечує обов'язковість наявності суб'єктивної сторони у складі правопорушення, вчиненого юридичною особою. Основною причиною цього вони вбачають відсутність у юридичної особи розуму та психічного ставлення щодо вчинених нею діянь, що унеможливлюе застосування до юридичної особи класичного підходу до розуміння поняття «вина» [5, с. 147].

Факт неможливості застосування поняття «вина» до юридичної особи пояснюється тим, що дане поняття завжди стосувалося фізичної особи i визначалося як негативне психічне ставлення особи до соціальних цінностей та норм соціальної поведінки та психічне ставлення особи до власної протиправної поведінки та її наслідків. Складовими елементами такої протиправної поведінки $€$ такі поняття, як «інтелект» та «воля». Прихильниками даної теорії обгрунтовується ідея відповідальності без вини. Вина юридичних осіб, безсумнівно, має свою особливу природу та виступає як складне соціально-психологічне явище, як вина всього колективу, а не тільки окремого його працівника [8, с. 209].

У рамках юридичної особи кожна людина виконує певні функції, які визначаються її місцем в даній організації. Але фізичні особи, що обіймають керівні посади в організації, наділені правом виступати від імені юридичної особи, тобто через власну волю формувати волю всієї організації юридичної особи, робити можливою її участь як самостійного суб'єкта у певних правовідносинах.

Деякі дослідники вважають, що вину юридичної особи можна ототожнювати як 3 виною конкретного працівника, так і з виною органів юридичної особи. У такому разі вина працівника є необхідною умовою вини юридичної особи, а вина юридичної особи може бути наслідком вини працівника [3, с. 230]. Така позиція дає можливість виділити дві форми вини юридичних осіб, які виникають через дії фізичних осіб: по-перше, фізична особа усвідомлює протиправний характер своїх дій чи бездіяльності, передбачає шкідливі наслідки та вчиняє їх; по-друге, фізична особа не усвідомлюе, що ії дії чи бездіяльність можуть призвести до вчинення юридичною особою протиправного діяння, вчиняє таке діяння, хоча повинна була усвідомити характер свого діяння і могла передбачити настання шкідливих наслідків для навколишнього природного середовища.

Таким чином, дієздатність юридичної особи зумовлена дієздатністю окремих фізичних осіб, що входять до їі складу. Діяльність цих осіб, зумовлена їх посадовими обов'язками, тягне за собою виникнення для юридичної особи суб'єктивних прав і обов'язків. Зокрема, В.Б. Авер'янов вважає, що для визначення того, чи є дії юридичної особи винними, необхідно визначити, чи є вони наслідком дій або бездіяльності фізичних осіб, що входять до складу юридичної особи. Протиправні дії юридичної особи можна вважати винними, якщо вони є наслідком дій або бездіяльності фізичних осіб, що входять до складу юридичної особи. Тобто якщо юридичним фактом, що лежить в основі протиправних дій юридичної особи, є дії фізичних осіб, то дії юридичної особи можна визнати винними. Якщо ж такою основою є події, тобто фактичні обставини, виникнення яких не залежить від волі та свідомості фізичних осіб, що входять до складу юридичної особи, то такі дії юридичної особи вважати винними не можна $[1$, с. 165$]$.

Прихильники вищевикладеної позиції визначають вину юридичної особи як психічне (свідоме) ставлення фізичних осіб, що входять до складу 
юридичної особи, до зв' язку між їх діями (бездіяльністю) і протиправними діями юридичної особи.

Проте деякі вчені взагалі проти визначення вини як психічного ставлення особи до вчиненого злочину, оскільки вина полягає в нехтуванні тими цінностями, які охороняються правовими нормами. «Якщо ж брати до уваги, що вина далеко не у всіх випадках характеризується психічним ставленням, але обов'язково включає негативне ставлення суспільства до скоєного діяння, - зазначає С.В. Векленко, - то з боку юридичних осіб цілком можливе нанесення шкоди охоронюваним кримінальним законом цінностям» [2, с. 73].

A.C. Нікіфоров підкреслював, що принциповою підставою визнання юридичної особи суб'єктом злочину є специфічний причинно-наслідковий зв'язок і вина. Він стверджує, що організація делегує органу, який нею керує, прийняття та виконання стратегічних рішень. Такі рішення й поведінка, що на них базується, за своїм юридичним змістом є рішеннями та поведінкою організації, тому вона повинна нести відповідальність. Деякі вчені пропонують застосувати до юридичної особи так званий інститут безвинної (суворої, абсолютної) відповідальності. Така відповідальність настає за наявності об'єктивної сторони складу злочину, коли встановлений сам факт порушення закону з боку юридичної особи і він не потребує доведення вини [3, с. 17].

Здійснивши аналіз основних концепцій вини юридичної особи у вітчизняній кримінально-правовій доктрині та зважаючи на необхідність реформування кримінального законодавства, можна погодитись 3 тими вченими, які відстоюють позицію визнання юридичної особи суб’єктом злочину та вважають, що вина юридичної особи проявляється через винну поведінку її працівників, які контролюють здійснення юридичною особою її прав та обов' язків.

Таким чином, вина юридичної особи може бути визначена як психічне ставлення фізичних осіб, які мають право діяти від імені юридичної особи, до зв’язку між їхніми діями (бездіяльністю) та протиправними діями юридичної особи.

\section{Jimepamypa}

1. Адміністративне право України. Академічний курс : підручник. У двох томах. Том 1. Загальна частина / ред. колегія: В.Б. Авер'янов (голова). Київ : Видавництво «Юридична думка». 2004. 584 с.

2. Векленко С.В. Понятие, сущность, содержание и формы вины в уголовном праве. Омск, 2002. $192 \mathrm{c.}$

3. Гражданское право Украины : учебник. Часть 1 / А.А. Пушкин, В.М. Самойленко, Р.Б. Шишка и др. / под ред. А.А. Пушкина и В.М. Самойленко. Харьков : Основа.1996. 422 с

4. Конституція України : Закон України від 28.06.1996 р. № 254к/96-ВР / Верховна Рада України. Відомості Верховної Ради України (ВВР). 1996. № 30. Ст. 141. URL: https//zakon.rada.gov.ua/laws/ show $/ 254 \%$ D0 $\%$ BA $/ 96-\%$ D0 $\%$ B2 $\%$ D1 $\% 80$ (дата звернення: 15.09 .2019$)$.

5. Кримінальна відповідальність юридичних осіб: порівняльно-правове дослідження : монографія / В.К. Грищук, О.Ф. Пасєка. Львів. держ. ун-т внутр. справ. Львів : ЛДУВС, 2013. 247 с.

6. Кримінальний кодекс України : Закон України № 2341-III / Верховна Рада України. Відомості Верховної Ради Украӥни (ВВР). 2001. № 25-26. Ст. 131. URL: https://zakon.rada.gov.ua/laws/show/2341-14 (дата звернення: 15.09.2019).

7. Лихова С.Я. Юридичні особи як суб'єкти кримінальної відповідальності за КК України. Юридичний вісник. 2014. № 4 (33). С. 128-132.

8. Матвеев Г.К. Основания гражданско-правовой ответственности. Москва :Юрлитиздат. 1970.218 с.

9. Никифоров А.С. Юридическое лицо как субъект преступления и уголовная ответственность. Москва : Центр ЮрИнфоР. 2002. 204 с.

\section{Анотація}

Колос С. С. Вина юридичної особи у кримінально-правовій доктрині. - Стаття.

Стаття присвячена актуальній проблемі впровадження інституту кримінальної відповідальності юридичної особи, адже протягом тривалого часу у вітчизняній кримінально-правовій доктрині можливість визнання юридичних осіб суб'єктами кримінальної відповідальності не розглядалася.

Автором розглянуто дискусійне питання вини юридичної особи як одного 3 елементів складу злочину. Здійснено аналіз основних концепцій вини юридичної особи у вітчизняній науці кримінального права. Розглянуто нормативно-правові акти, які регулюють застосування заходів кримінально-правового характеру щодо юридичних осіб в Україні. У ході дослідження автором зроблено спробу визначити поняття вини юридичної особи у кримінальному праві.

Юридичні особи є повноправними суб'єктами великої кількості правовідносин і можуть вчиняти протиправні діяння. Водночас суттєвою відмінністю цих протиправних діянь є характер суб'єктивної сторони такого виду правопорушень. Ця характеристика правопорушення дістає відображення у понятті вини, яка характеризує свідоме ставлення особи до вчиненого нею протиправного діяння та його наслідків.

За результатами дослідження автор робить висновок, що вина юридичної особи може бути визначена як психічне ставлення фізичних осіб, які мають право діяти від імені юридичної особи, до зв'язку між їніми діями чи бездіяльністю та протиправними діями юридичної особи.

На думку автора, введення інституту кримінальної відповідальності юридичної особи є необхідним кроком у реформуванні кримінального законодавства. Оскільки у вітчизняній кримінально-правовій доктрині все ще відсутня науково обгрунтована концепція впровадження інституту кримінальної відповідальності юридичних осіб, то проблема вини юридичної особи залишається досить актуальною та потребує подальших досліджень.

Запровадження кримінальної відповідальності юридичних осіб є одним з найскладніших питань у реформуванні кримінального законодавства. Особливо гострі дискусії стосуються вини юридичної особи, адже основоположним принципом у вітчизняному кримінальному праві є принцип особистої і винної відповідальності, а вина є однією з обов'язкових ознак складу злочину. 
Ключові слова: кримінальна відповідальність юридичних осіб, концепція вини, вина юридичної особи, суб’єкт злочину, суб’єктивна сторона.

\section{Summary}

Kolos S. S. Guilt of a legal entity in the criminal law doctrine. - Article.

The article is devoted to the topical problem of introduction of the criminal liability institution of a legal entity, since for a long time in the domestic criminal law doctrine the possibility of recognition of legal entities as subjects of criminal liability was not considered.

The author discusses the issue of the guilt of a legal entity as one of the elements of the crime. The basic concepts of the guilt of a legal entity in the national criminal law science are analyzed. Regulatory acts regarding the application of criminal law measures against legal entities in Ukraine are considered. In the course of the research the author makes an attempt to define the concept of guilt of a legal entity in the criminal law.

Legal entities are full-fledged entities with many legal relationships and may commit unlawful acts. At the same time, a significant difference between these unlawful acts is the nature of the subjective side of such offenses. This characteristic of the offense is reflected in the notion of guilt, which characterizes the person's conscious, mental attitude to the wrongful act he has committed and its consequences.

According to the results of the research, the author concludes that the guilt of the legal entity can be defined as the mental attitude of natural persons who have the right to act on behalf of the legal entity, to the link between their actions or omissions and unlawful actions of the legal entity.

According to the author, the introduction of the criminal liability institution of a legal entity is a necessary step in the reform of criminal legislation. Since the national criminal law doctrine still lacks a scientifically sound concept of introduction of the institution of criminal liability of legal persons, the problem of guilt of the legal person remains quite topical and requires further research.

The introduction of criminal liability of legal entities is one of the most difficult issues in reforming criminal law. Particularly heated discussions relate to the guilt of the legal person, since the fundamental principle in domestic criminal law is the fault-based individual responsibility principle, and guilt is one of the obligatory features of the crime.

Key words: criminal liability of legal entity, concept of guilt, guilt of legal entity, crime, subject of crime, subjective party. 